\title{
The Development of MyGSP: An Online Resource for Teaching Mathematics Based on Geometer's Sketchpad (GSP)
}

\author{
Abdul Halim Abdullah ${ }^{1}$, Johari Surif ${ }^{1}$, Nor Hasniza Ibrahim ${ }^{1}$, Marlina Ali $^{1} \&$ Mohd Hilmi Hamzah ${ }^{2}$ \\ ${ }^{1}$ Faculty of Education, Universiti Teknologi Malaysia, Skudai, Malaysia \\ ${ }^{2}$ Language Academy, Universiti Teknologi Malaysia, Skudai, Malaysia \\ Correspondence: Abdul Halim Abdullah, Faculty of Education, Universiti Teknologi Malaysia, 81310 UTM \\ Skudai, Malaysia. Tel: 60-13-374-0024.E-mail: halim_aman@yahoo.com
}

$\begin{array}{lr}\text { Received: August 13, } 2014 & \text { Accepted: September 12, } 2014 \quad \text { Online Published: October 30, } 2014 \\ \text { doi:10.5539/ass.v10n22p227 } & \text { URL: http://dx.doi.org/10.5539/ass.v10n22p227 }\end{array}$

\begin{abstract}
MyGSP was developed following various constraints faced by teachers to integrate the Geometer's Sketchpad (GSP) software into mathematics lessons. Based on the Waterfall Design Model, the development of MyGSP started with the analysis of user needs through literature review and simple survey. From the analysis, three main constraints were identified: (1) insufficient time to prepare for GSP-aided lessons; (2) lack of training on GSP integration in lessons; and (3) lack of references for teaching mathematics using GSP. Therefore, taking into account the computer equipment currently available at schools, the researcher developed MyGSP to overcome these constraints. In the design phase, the researcher developed teaching materials for mathematics topics at secondary schools. Teaching strategies adopting higher order of thinking skills were applied in the teaching materials. Apart from this, video tutorials on GSP usage in teaching materials were also developed. In the implementation and unit testing phase, 30 pre-service Mathematics teachers participated by providing feedback on the materials developed. In the integration phase, the modules, i.e., Teaching Material Module, Download Module, Forum Module, and Video Tutorial Module, were combined into one system known as MyGSP. The MyGSP system was also updated and enhanced from time to time in the maintenance phase. It is hoped that MyGSP will be able to fulfill teachers' needs for integrating GSP into their classrooms.
\end{abstract}

Keywords: geometer's sketchpad, higher order thinking skills, GSP-aided lessons

\section{Introduction}

Education technology is highly encouraged to be used for the purpose of teaching and learning Mathematics in classrooms. According to the Curriculum Development Division (Bahagian Pembangunan Kurikulum, BPK) of the Malaysian Ministry of Education (MOE, 2011), the use of technology is very much emphasised in teaching and learning mathematics to provide room and opportunity for students to explore and deepen their understanding on mathematical concepts. According to BPK (2011), the use of education technology including educational software can enhance a pedagogical approach and in turn increase the understanding of mathematical concepts. In the Malaysian education system, one of the education technologies introduced specifically in the Mathematics subject is the Geometer's Sketchpad (GSP) software. The use of this dynamic geometry software has been mentioned explicitly in the Discourse on Secondary School Mathematics Subject Syllabus as a method or an approach proposed to be included into teaching and learning activities to introduce various mathematics concepts (BPK, 2011). In the specification for secondary school mathematics curriculum for form 1 to form 5, 29.51\% (18 topics) are proposed to be taught using dynamic geometry software such as GSP. MOE has gone the extra mile by obtaining a license to use the GSP software for teaching and learning purposes in Malaysia. At a global level, the National Council of Teachers of Mathematics (NCTM, 2002) has proposed the use of dynamic geometry software such as GSP to assist students in learning mathematics. NCTM fully supports the use of GSP in teaching and learning for students to expand their reasoning skills.

Many past studies have shown that the use of computer software, specifically the dynamic geometry software, has enabled students to harness their higher order thinking skills (HOTS) in mathematics. Choi-Koh (1999) and Nik Azis (2008), for instance, state that the environment for dynamic geometric software (1) enables students to expand their concrete mathematics experience to a more formal level, (2) encourages their enthusiasm to form conjecture, and (3) increases their mathematical thinking. This matter is supported by Norazah et al. (2010) and 
Kerrigan (2002) who both emphasise that students' HOTS can be harnessed through exploratory learning and discussion using the GSP software. According to Newman (2000), the use of dynamic geometry software can increase students' desire to know, boost their intellect and challenge their intellectual capability. Besides, the features found in dynamic geometry software allow students to form conjecture. According to Manizade and Lundquist (2009), through involvement in activities based on dynamic geometry software, students will take part in mathematical thinking that will bring them to form their conjecture. Dynamic geometry software can help students to form and hold discourse on conjecture, which are the bases for generalising a certain pattern formed during exploration (Glass et al., 2001). This process can further motivate students to discuss whether the conjecture is true or not (Lange, 2002). Students might also find examples that contradict each other, and this will lead them to form new conjecture (Hirschorn \& Thompson, 1996).

The ability of GSP to increase students' HOTS is seen as relevant today and is in line with approaches that emphasize HOTS in the Malaysian education system. HOTS are particularly relevant following Malaysian students' decline in international assessments namely Trends in International Mathematics and Science Study (TIMSS) and Programme for International Student Assessment (PISA) that assess the HOTS of students. According to MOE, teachers' lack of emphasis on HOTS has slowed down the implementation of Integrated Curriculum for Primary Schools (KBSR) and Integrated Curriculum for Secondary Schools (KBSM) in the classroom. It is also stated in the Malaysian Education Development Plan (2013-2025) that school leavers have to be equipped with HOTS in order to compete at a global level. Following this, the Teacher Education Division has prepared an outline for the implementation of HOTS in the classroom, in which changes in teaching approaches are particularly emphasized. In this context, the use of technology in the lesson can potentially harness the HOTS of students.

\section{Problem Background}

A study by Hadi and Zainab (2012) shows that, although teachers may have high desire to use ICT in classrooms, lack of time can be a constraint for them to achieve this. The main reason for this is that ample time is needed for teachers to plan and execute technology-aided lessons in classrooms (Challoo \& Weaver, 2007; Vrasidas et al., 2010; Becta, 2004). In Mathematics subject, although the GSP software is provided in schools and it is very much encouraged to use them in the teaching and learning process, past studies have shown that mathematics teachers do not use the GSP software due to several factors. One of the factors is limited opportunity to attend courses on the use of GSP. In the Malaysian education system, courses and workshops on the application of GSP software have been conducted for Mathematics teachers (Kedah Education Department, 2009; Kamawati, 2006). However, these courses do not require participation from all or the majority of secondary school Mathematics teachers in Malaysia. Agyei dan Voogt (2010), Ozden (2007), and Topracki (2006) agree that there is a lack of training opportunity available for teachers in integrating education technology into the classroom. According to Kalsom and Lim (2013), among the reasons for not using the GSP software include (i) lack of exposure on GSP usage, (ii) no exposure on GSP, (iii) no exposure from any party although one is rather interested in using it, and (iv) limited courses available on GSP.

Among teachers who have attended workshops or courses on GSP software usage, past studies have found that these teachers have not taken advantage of the GSP software provided. This is due to lack of resources to refer to on teaching Mathematics subject with the aid from the GSP software. According to Haslina et al. (2000), although teachers attend certain courses with hands-on activities included, the modules or manuals are not provided for participants' use after the workshop. Therefore, the other main reason is due to lack of references in using education technology including GSP software (Gomes, 2005; Shazia, 2000; Clarke, 2007; Ertmer \& Otternbreit-Leftwich, 2010; Becta, 2004). Agyei and Voogt (2010) suggest that a user-friendly environment be built on education technology application for teachers' reference. However, according to Khalid (2009), access to reference sources on certain education technology can be improved through self-training on the Internet.

Based on the problems that prevent the usage of the GSP software among teachers, the researcher developed a mathematics teaching material for form one to form five in accordance to secondary school mathematics syllabus based on the GSP software. It is hoped that these teaching materials will be able to resolve problems faced by teachers and they can be used as a reference in the classroom.

\section{Objectives of Study}

1) To develop teaching materials based on GSP for form one to form five in Mathematics; and

2) To develop a MyGSP system that can organize the teaching materials developed. 


\section{Methodology of the Study}

As shown in Figure 1, the Waterfall Model was chosen as the model to develop MyGSP. This model was chosen because of the clear division of its components. There are five phases used in this model: (i) Needs Analysis; (ii) System Design; (iii) Execution and Unit Testing; (iv) Integration and Unit Testing; and (v) Operation and Maintenance.

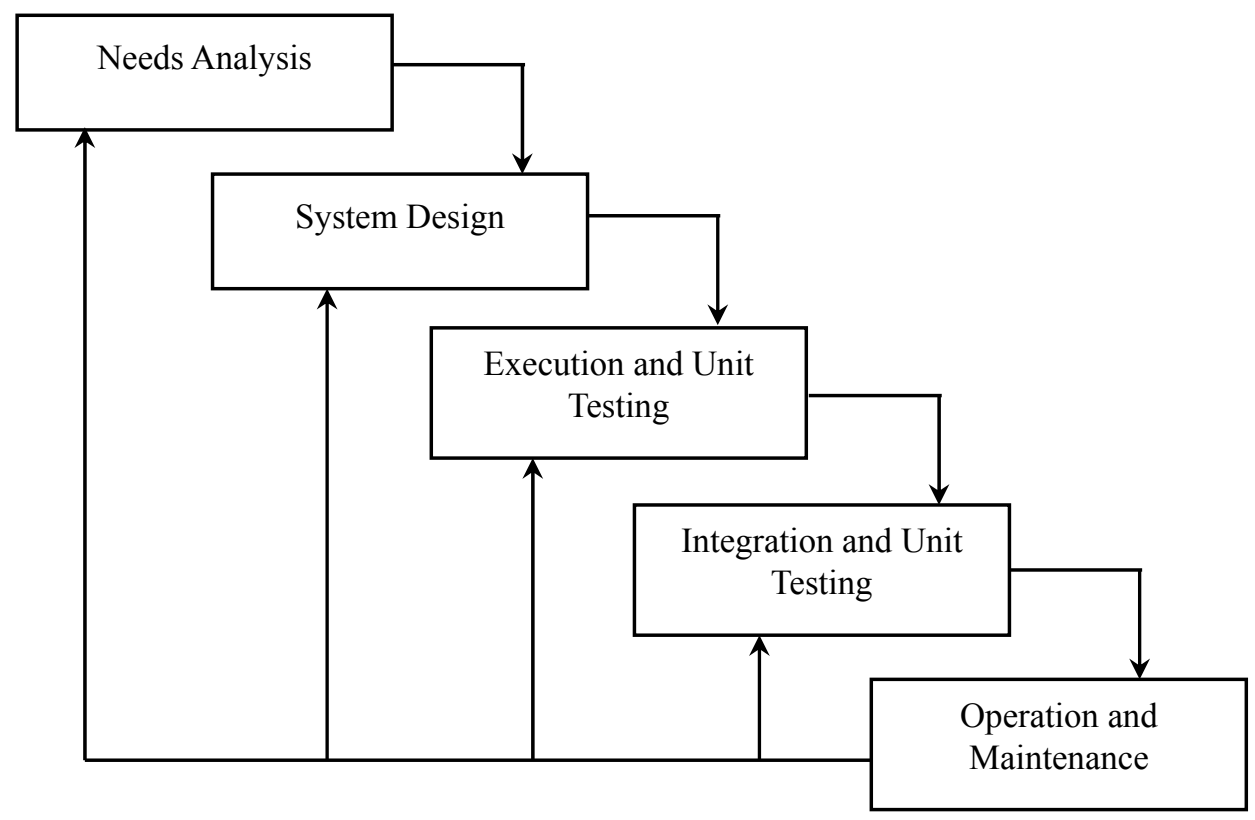

Figure 1. Waterfall design model

\subsection{Analysis Phase}

The analysis on the main problems faced by teachers in using this GSP software in their lessons was done. The analysis was conducted through literature review and a simple survey carried out on 23 Mathematics teachers from MARA Junior Science College all over Malaysia. Based on the literature review, Figure 2 below reveals three main factors leading to the underuse of GSP software by teachers in teaching Mathematics.

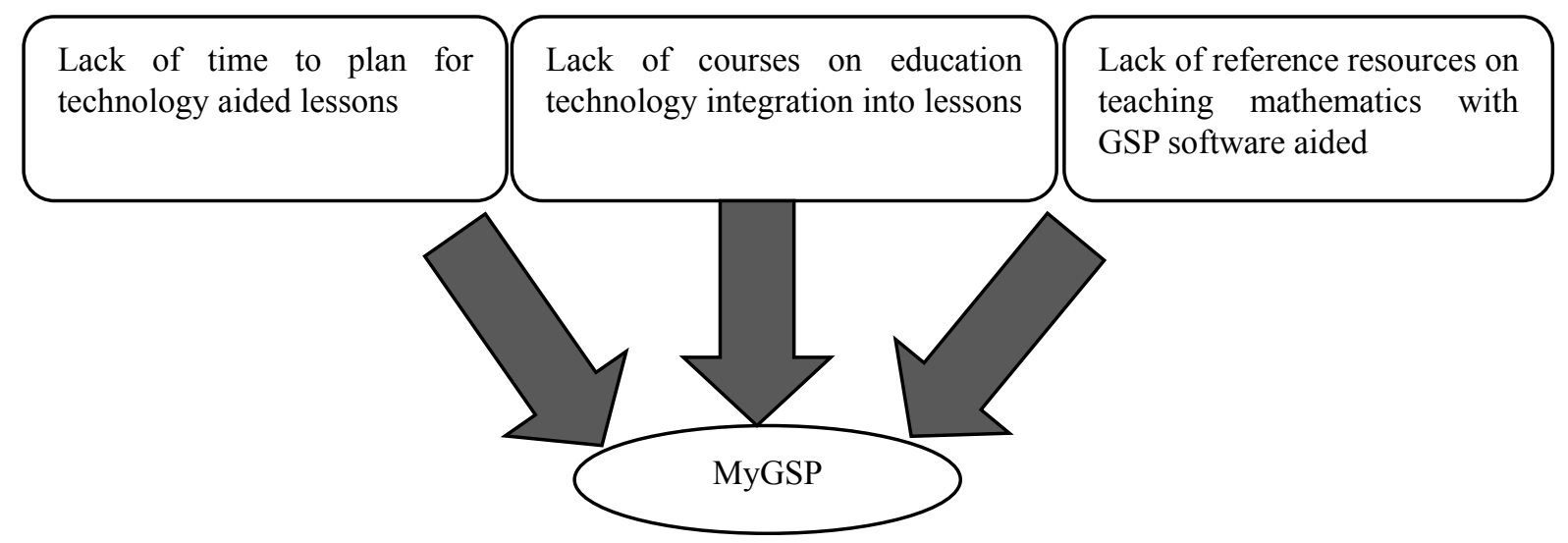

Figure 2. Three factors deterring teachers from using GSP

Besides, a simple survey was also carried out on Mathematics teachers from MARA Junior Science College to find out the level of GSP usage in teaching and learning Mathematics using an instrument adapted from a study by Norhana Aini (2008). As shown in Table 1, the findings of the study showed that the majority of teachers were at level 1 (non-use), i.e., $43.5 \%$. Meanwhile, the lowest percentage was $0 \%$ for level 6 (renewal), indicating that none of the teachers was at this level. 
Table 1. Level of GSP usage among teachers

\begin{tabular}{lll}
\hline Level & Description & Percentage \\
\hline Level 0 & $\begin{array}{l}\text { Teacher has little knowledge on GSP usage in teaching and learning (T\&L) } \\
\text { Mathematics. However, the teacher is not involved in using it and has not done } \\
\text { anything to be involved in its application. }\end{array}$ & $43.5 \%$ \\
Level 1 & $\begin{array}{l}\text { Teacher actively searches and acquires information on the use of GSP in T\&L } \\
\text { Mathematics. }\end{array}$ & $21.7 \%$ \\
Level 2 & $\begin{array}{l}\text { Teacher is ready to use GSP for the first time in T\&L Mathematics. } \\
\text { Level } 3\end{array}$ & $\begin{array}{l}\text { Teacher pays attention to a short-term application of daily GSP usage with some time } \\
\text { allocated for reflection. Teacher also works towards reinforcing it. }\end{array}$ \\
Level 4 & $\begin{array}{l}\text { Teacher feels at ease using GSP. However, not much effort is put into it. Teacher barely } \\
\text { considers increasing the application of GSP in T\&L Mathematics. }\end{array}$ & $4.3 \%$ \\
Level 5 & $\begin{array}{l}\text { Teacher cooperates with fellow teachers in carrying out relevant activities to increase } \\
\text { the impact of GSP in the classroom. }\end{array}$ & $4.3 \%$ \\
Level 6 & $\begin{array}{l}\text { Teacher re-evaluates the quality of GSP usage in T\&L Mathematics, makes changes or } \\
\text { finds alternatives to enable innovation to be presented in a way that can provide } \\
\text { maximum impact, and explores new goals for the school. }\end{array}$ & $0.0 \%$ \\
\hline
\end{tabular}

Table 2 shows the conclusion that can be made on the condition of equipment found at MARA Junior Science College (MRSM). The analysis showed that most schools were sufficiently equipped with facilities such as laptops, LCD (projectors) and screens.

Table 2. Current condition of school equipment

\begin{tabular}{llllll}
\hline Equipment & Available & Unavailable & Broken & Unsure & Not enough \\
\hline Laptop & 21 & 0 & 0 & 1 & 1 \\
LCD (projector) & 14 & 3 & 0 & 1 & 3 \\
Screen & 14 & 3 & 0 & 1 & 2 \\
\hline
\end{tabular}

Based on the finding from the needs analysis, most of the teachers were found to have insufficient time to plan and develop teaching materials that were GSP-aided. They also had a limited opportunity to attend courses on GSP usage in lessons. Besides, the lack of resources on GSP software was also the main constraint for teachers to use it in the classroom. A survey conducted through questionnaires also found that most teachers had little knowledge on the use of GSP in T\&L of Mathematics. That is, they were not involved in its use and did nothing to take part in its usage. They were also searching for and acquiring information on the use of GSP in T\&L of Mathematics. Therefore, the development of MyGSP has the potential to resolve constraints faced by teachers in using the GSP software in their lessons. In addition, most teachers also agreed that their schools had sufficient facilities such as laptops, LCD and screens, which were hoped to facilitate their GSP-aided lessons.

\subsection{Design Phase}

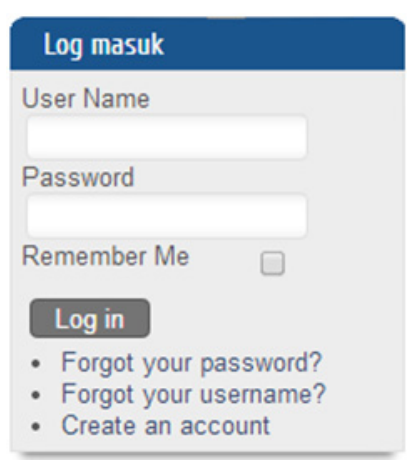

Figure 3. User login 
The second phase, which is design phase, involved producing modules to be included into MyGSP. This phase translated what was needed into something that can be seen physically. The purpose of this phase was to produce a system that fulfilled the needs. Among the modules involved in this system were Download Module, Teaching Material Module, Forum Module and Video Tutorial Module. Teaching Material Module consisted of explanations for the GSP-aided teaching activities prepared. However, users would not be able to download the available teaching materials until they have registered themselves, as shown in Figure 3.

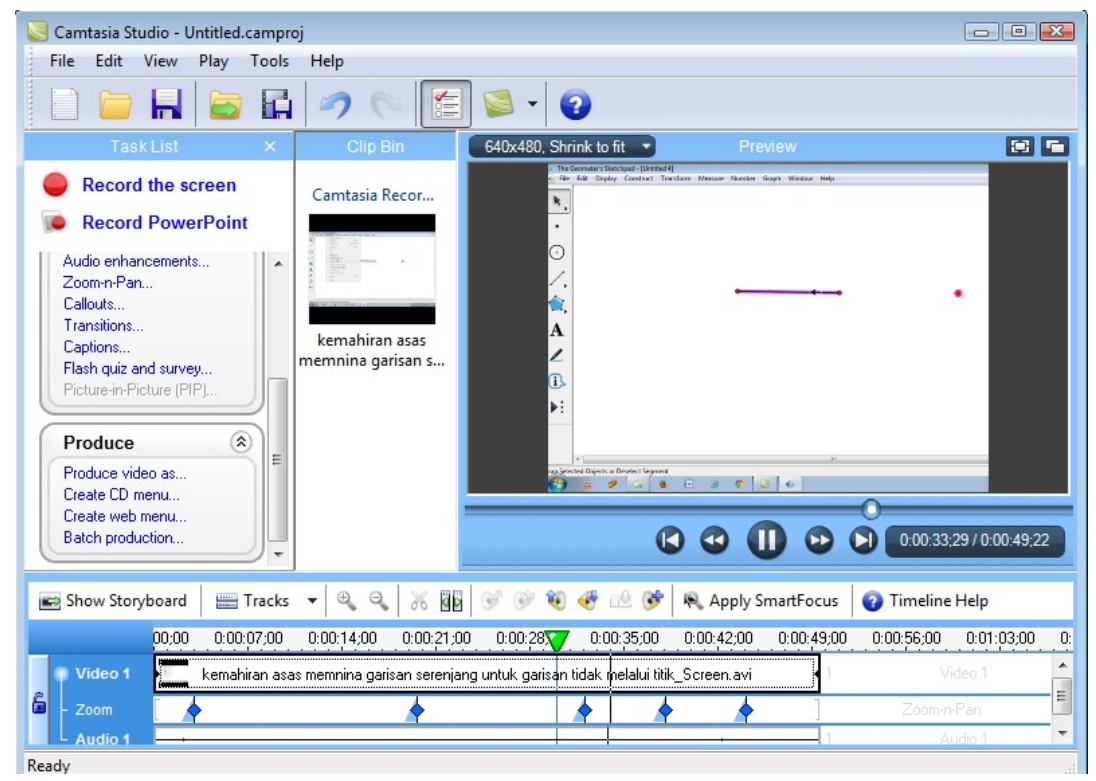

Figure 4. Camtasia studio to develop video tutorials

Download Module allows registered users to download GSP-aided Mathematics teaching materials that are available in two formats namely .pdf and .doc. Teaching materials prepared using .pdf format allow users to directly use the materials in lessons. On the other hand, doc format allows teachers to make changes to the materials according to the teachers' preference and suitability. The Download Module also contains a teaching material namely Introduction to GSP. According to Nik Azis (2008), the use of technology in the teaching and learning process comes with some pre-conditions; students need to have access to the required technology, understand the equipment, and have grasp of the main skills needed to be able to use it. Among the items found in the Introduction to GSP are drawing dots and lines, measuring length, labelling dots, lines and angles, and measuring angles. The Download Module also allows registered users to download video tutorials on GSP usage in teaching materials, other than allowing videos to be viewed online and through the Video Tutorial Module. According to Jamaluddin and Zaidatun (2005), the use of videos in lessons completes the process of delivering information and enables teachers and students to form deeper understanding of the material. The software used in the development of MyGSP is Camtasia Studio, as shown in Figure 4.

GSP-aided teaching materials are prepared by applying learning strategies that can generate students' HOTS. These strategies include discovery learning strategy, contextual learning strategy and forming conjecture learning strategy.

\subsubsection{Discovery Learning Strategy}

Discovery learning has long been proposed by MOE to be used in teaching Mathematics in secondary schools (Curriculum Development Division, 2011). According to BPK, such a teaching strategy is able to stimulate the teaching and learning environment in and out of the classroom. Discovery learning occurs when the main concept and principle are studied and discovered by the students on their own. According to Bruner (1966), the discovery occurs when students use their own mental process to obtain a concept or a principle. In other words, students are no longer being spoon-fed with the concept, principle, formula, etc.; instead, they make discovery on their own. According to Rooney (2012), teaching and learning based on discovery learning can induce the students' HOTS. This is due to the fact that the strategy involves a lot of processes related to students' HOTS, such as discovering and forming the conjecture (Aarnes \& Knudtzon, 2003; Habre, 2009). This teaching method 
has become easier and more effective with the aid of dynamic geometry software such as GSP (Reinhard, 2001). Studies by Olkun et al. (2005) and Guven (2012) have found that dynamic geometry software can be used by students to explore the relationships in mathematics. Van de Walle (2004) even adds that the students' skills in exploring the mathematical relationships using the dynamic geometry software cannot be achieved in other learning environments. On top of that, Olkun et al. (2005) found that students who were given problems to be solved using the dynamic geometry software were able to find more than one solution to the problems. Due to the effectiveness of discovery learning strategy in enhancing the students' HOTS, the strategy was applied in the development of the teaching materials in MyGSP.

\subsubsection{Contextual Learning Strategy}

Contextual learning is a learning method that combines the content with the individual's everyday experience, community, and work environment. Contextual learning can also enhance students' HOTS (Berns, 2001). This type of learning provides a concrete learning involving hands-on and minds-on activities (BPK, 2009), and its implementation in the classroom is highly recommended (BPK, 2011). In contextual learning, students build their knowledge based on their past experience through the real-life context integrated in the teaching process (Wilkinson, 1999). Teaching using contextual approach is in line with the concept of mathematical questions in the PISA assessment. In this study, the questions provided in the assessment were adapted to suit the local context and focused more on the ability of students to apply in their lives about what they learn in school. Most of the questions in PISA required students to use their HOTS. Apart from that, a study by Gecua and Ozdener (2010) shows that the combination of the GSP software and digital photos depicting students' daily lives gives a positive effect on the students' knowledge retention and achievement. Therefore, GSP-aided contextual learning strategy was also applied in this study.

\subsubsection{Forming Conjecture Learning Strategy}

Conjecture is a statement that has yet to be proven but appears true (Chazen \& Houda, 1989). In mathematics, a conjecture is a statement that has not been proven or a theorem that appears true, and it is formed when the relationships observed by the students appear to be consistently true (Noraini, 2005). The students make generalisation based on what they observe in the data and patterns. The processes involved in this teaching strategy of conjecture formation include data observation by the students, patterns identification, and finally generalisation (Guven \& Karatas, 2009; Shiang-tung \& Feng-chu, 2008). The generalization is a statement made based on inductive reasoning, i.e., a general conclusion produced based on specific examples (Gillis, 2005). Activities that promote conjecture formation will stimulate the development of students' intellectual processes. Technologies such as dynamic geometry software enable students to form conjecture and to test the conjecture. According to Glass et al. (2001), Abdullah and Effandi (2012), dynamic geometry software can help students develop conjecture and argue about the conjecture that is actually the basis of the generalization of a pattern formed during discovery. This process then motivates students to discuss whether the conjecture is true or not (Lange, 2002). It is also possible for students to find contradicting examples that lead to the formation of a new conjecture (Hirschorn \& Thompson, 1996). Through involvement in activities based on technologies such as the dynamic geometry software, students will engage in mathematical thinking that leads to their conjecture formation (Manizade \& Lundquist, 2009; Abdullah \& Effandi, 2012). According to Guven and Karatas (2009), Abdullah and Effandi (2013), the dragging option in the dynamic geometry software allows students to investigate a conjecture faster and more easily.

Table 3 shows some examples of application of three learning strategies in the teaching materials.

The purpose of Forum Module is for teachers to discuss their experience using the teaching materials developed and provided in MyGSP. Besides that, the Forum Module can be a platform for teachers to provide feedback regarding the teaching materials in MyGSP. Any constructive feedback will be evaluated to improve the program further in the future.

\subsection{Implementation and Unit Testing Phase}

The teaching materials developed were shown to a group of 30 pre-service teachers who were taking the Degree in Mathematics Education. As shown in Table 4, the first section of the survey asked the pre-service teachers to evaluate the effectiveness of the GSP software. The overall mean value for the first section was 3.94.

The second section of the survey asked the pre-service teachers' perception towards the GSP-based teaching materials developed. The overall mean value for this section was 3.96. According to Table 5, items with the highest mean values in this section were item 7 and item 9 . 
Table 3. Application of learning strategies in the teaching materials

Discovery

Learning

Contextual

Learning
Examples of GSP-aided activities developed

\section{Finding the Pi value $(\pi)$}

Students are asked to search for images of a $\mathrm{CD}$, an orange, and a clock using Google Image. Right-click on the image chosen, choose 'Save image', and save it on the Desktop. Students are asked to drag the images of the $\mathrm{CD}$, orange, and clock from the Desktop to the readily opened GSP program.
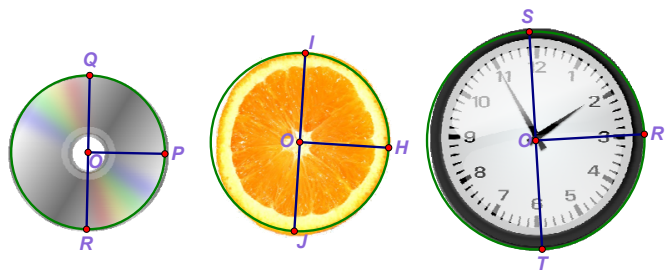

In the GSP environment, students are asked to obtain the circumference and diameter of the objects and calculate the circumference to diameter ratio of the objects.

\begin{tabular}{|c|c|c|c|}
\hline \multirow[b]{2}{*}{ Object } & \multirow[b]{2}{*}{ Circumference $(\mathrm{cm})$} & \multicolumn{2}{|r|}{ Ratio } \\
\hline & & Diameter $(\mathrm{cm})$ & $\left(\frac{\text { Circumferemce }}{\text { Diameter }}\right)$ \\
\hline \multicolumn{4}{|l|}{ CD } \\
\hline \multicolumn{4}{|l|}{ Orange } \\
\hline Clock & & & \\
\hline
\end{tabular}

State the conclusion that can be made based on the ratios obtained.

\section{Understanding the Concept of Loci in Two Dimensions}

Observe the following picture:

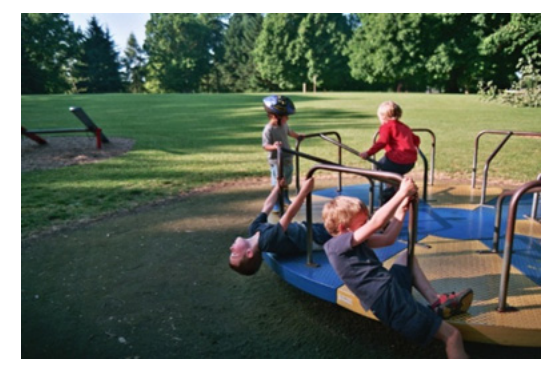

How do you determine the locus of rotation for the merry-go-round?

Using GSP, students are asked to develop a locus of one fixed point. First, students need to draw a circle and draw a point on its circumference. Click on the point and click on the Dropdown menu list-Edit and click on Animation. A dialogue box of Properties of Action Button Animate Point will appear.

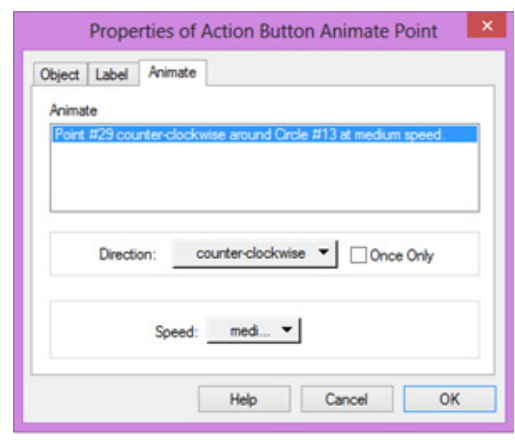

To make the point move, click on the button Animate Point. 
Learning strategy Examples of GSP-aided activities developed

Click on the moving point and click on the Dropdown menu list-Display and Trace Point. Students will see that the locus formed from the moving point has a constant distance from the fixed point.

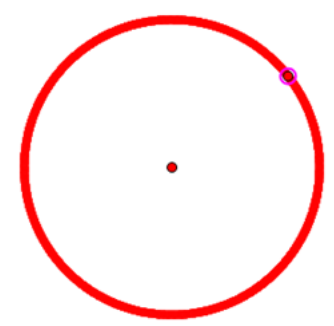

Finding the relationship between an angle at the centre and the angle at the circumference subtended by the same arc length

Using GSP, students draw a circle. On the circle, draw three points anywhere on the circumference. Connect the points and the centre of the circle to form chords and radius.

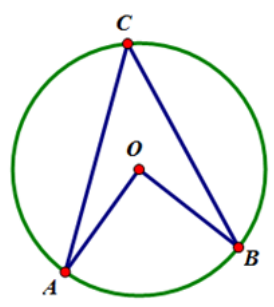

Find the value of angle AOB and ACB.

Forming

Conjecture

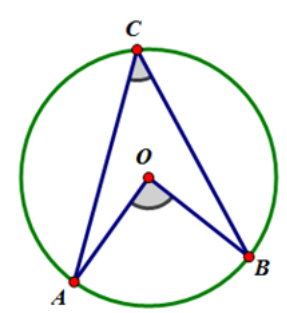

Students then click on the values for all angles, go to Drop-Down Menu, Number and choose Tabulate. A table that shows values for angles AOB and ACB will be formed.

Click twice on the values in the table, then move any point on the circle and watch the values of angles produced. Repeat the process until several values of angles AOB and ACB are obtained.

\begin{tabular}{||c|c||}
\hline \hline$m \angle A O B$ & $m \angle A C B$ \\
\hline $87.61^{\circ}$ & $43.81^{\circ}$ \\
\hline $87.61^{\circ}$ & $43.81^{\circ}$ \\
\hline $118.07^{\circ}$ & $59.03^{\circ}$ \\
\hline $118.07^{\circ}$ & $59.03^{\circ}$ \\
\hline
\end{tabular}

What is your conclusion on the relationship between the angle at the centre and the angle at the circumference subtended by arcs of the same length? 
Table 4. The perception of pre-service teachers towards the GSP software

\begin{tabular}{|c|c|c|c|c|c|c|c|c|c|c|c|c|}
\hline & \multirow{2}{*}{ Item } & \multicolumn{2}{|c|}{ SD } & \multicolumn{2}{|l|}{ D } & \multicolumn{2}{|c|}{ NS } & \multicolumn{2}{|l|}{ A } & \multicolumn{2}{|c|}{ SA } & \multirow{2}{*}{ Min } \\
\hline & & $\mathrm{n}$ & $\%$ & $\mathrm{n}$ & $\%$ & $\mathrm{n}$ & $\%$ & $\mathrm{n}$ & $\%$ & $\mathrm{n}$ & $\%$ & \\
\hline 1 & This GSP software is easy to learn. & 1 & 3.33 & 0 & 0 & 2 & 6.67 & 20 & 66.67 & 7 & 23.33 & 4.17 \\
\hline 2 & $\begin{array}{l}\text { The use of GSP can encourage students } \\
\text { to perform activities actively. }\end{array}$ & 0 & 0 & 1 & 3.33 & 4 & 13.33 & 19 & 63.33 & 6 & 20.00 & 4.00 \\
\hline 3 & $\begin{array}{l}\text { This GSP is suitable for students of all } \\
\text { backgrounds. }\end{array}$ & 0 & 0 & 3 & 10.00 & 7 & 23.33 & 17 & 56.67 & 3 & 10.00 & 3.67 \\
\hline 4 & $\begin{array}{l}\text { This GSP is suitable for teachers of all } \\
\text { backgrounds. }\end{array}$ & 1 & 3.33 & 0 & 0 & 5 & 16.67 & 20 & 66.67 & 4 & 13.33 & 3.87 \\
\hline 5 & $\begin{array}{l}\text { GSP is very useful as a teaching aid in } \\
\text { KBSM Mathematics. }\end{array}$ & 0 & 0 & 1 & 3.33 & 2 & 6.67 & 19 & 63.33 & 8 & 26.67 & 4.13 \\
\hline 6 & $\begin{array}{l}\text { The use of GSP as ABM is very } \\
\text { effective in the students' learning } \\
\text { process. }\end{array}$ & 0 & 0 & 0 & 0 & 5 & 16.67 & 18 & 60.00 & 7 & 23.33 & 4.07 \\
\hline 7 & $\begin{array}{l}\text { GSP is able to help students understand } \\
\text { the concept of Mathematics better. }\end{array}$ & 0 & 0 & 3 & 10.00 & 6 & 20.00 & 18 & 60.00 & 3 & 10.00 & 3.70 \\
\hline
\end{tabular}

* $\mathrm{SD}=$ Strongly Disagree, $\mathrm{D}=$ Disagree, $\mathrm{NS}=$ Not Sure, $\mathrm{A}=$ Agree, $\mathrm{SA}=$ Strongly Agree

Table 5. The perception of pre-service teachers towards teaching materials

\begin{tabular}{|c|c|c|c|c|c|c|c|c|c|c|c|c|}
\hline & \multirow{2}{*}{ Item } & \multicolumn{2}{|c|}{ SD } & \multicolumn{2}{|l|}{$\mathrm{D}$} & \multicolumn{2}{|c|}{ NS } & \multicolumn{2}{|l|}{$\mathrm{A}$} & \multicolumn{2}{|c|}{ SA } & \multirow{2}{*}{ Min } \\
\hline & & $\mathrm{n}$ & $\%$ & $\mathrm{n}$ & $\%$ & $\mathrm{n}$ & $\%$ & $\mathrm{n}$ & $\%$ & $\mathrm{n}$ & $\%$ & \\
\hline 1 & $\begin{array}{l}\text { KBSM learning objectives are } \\
\text { practical and can be achieved using } \\
\text { GSP. }\end{array}$ & 0 & 0 & 0 & 0 & 7 & 23.33 & 19 & 63.33 & 4 & 13.33 & 3.90 \\
\hline 2 & $\begin{array}{l}\text { The GSP-based teaching materials } \\
\text { developed are in line with the KBSM } \\
\text { Mathematics syllabus. }\end{array}$ & 0 & 0 & 0 & 0 & 8 & 26.67 & 17 & 56.67 & 5 & 16.67 & 3.90 \\
\hline 3 & $\begin{array}{l}\text { The objectives of teaching sources } \\
\text { cover multiple levels of students' } \\
\text { thinking skills. }\end{array}$ & 0 & 0 & 1 & 3.33 & 5 & 16.67 & 22 & 73.33 & 2 & 6.67 & 3.87 \\
\hline 4 & $\begin{array}{l}\text { The statement of objectives is clear } \\
\text { and easy to understand. }\end{array}$ & 0 & 0 & 0 & 0 & 2 & 6.67 & 24 & 80 & 4 & 13.33 & 4.07 \\
\hline 5 & $\begin{array}{l}\text { The activities provided can help } \\
\text { students master a mathematical } \\
\text { concept. }\end{array}$ & 0 & 0 & 1 & 3.33 & 5 & 16.67 & 22 & 73.33 & 2 & 6.67 & 3.83 \\
\hline 6 & $\begin{array}{l}\text { These teaching materials can create a } \\
\text { fun learning environment. }\end{array}$ & 2 & 6.67 & 0 & 0 & 4 & 13.33 & 15 & 50 & 9 & 30 & 3.97 \\
\hline 7 & $\begin{array}{l}\text { These teaching materials are suitable } \\
\text { for teaching and learning. }\end{array}$ & 0 & 0 & 1 & 3.33 & 1 & 3.33 & 16 & 53.33 & 12 & 40 & 4.30 \\
\hline 8 & $\begin{array}{l}\text { These teaching materials can } \\
\text { stimulate the students' HOTS. }\end{array}$ & 1 & 3.33 & 2 & 6.67 & 10 & 33.33 & 12 & 40 & 5 & 16.67 & 3.60 \\
\hline 9 & $\begin{array}{l}\text { Students can collect data from the } \\
\text { activities provided in the teaching } \\
\text { materials. }\end{array}$ & 0 & 0 & 0 & 0 & 2 & 6.67 & 18 & 60 & 10 & 33.33 & 4.23 \\
\hline 10 & $\begin{array}{l}\text { Students can see the data pattern } \\
\text { through the activities in the teaching } \\
\text { materials. }\end{array}$ & 0 & 0 & 0 & 0 & 6 & 20 & 16 & 53.33 & 8 & 26.67 & 4.07 \\
\hline 11 & $\begin{array}{l}\text { Students can make generalisation } \\
\text { based on the data obtained. }\end{array}$ & 0 & 0 & 1 & 3.33 & 9 & 30 & 13 & 43.33 & 7 & 23.33 & 3.87 \\
\hline
\end{tabular}

*SD=Strongly Disagree, $\mathrm{D}=$ Disagree, $\mathrm{NS}=$ Not Sure, $\mathrm{A}=$ Agree, $\mathrm{SA}=$ Strongly Agree 
The third section asked the perception of pre-service teachers towards the technical aspects in the GSP-aided teaching materials developed. The overall mean value for this section was 4.03. The item with the highest mean value was item 3 , which stated that the activities in these teaching materials are easy to follow.

Table 6. The perception of pre-service teachers towards the technical aspects

\begin{tabular}{|c|c|c|c|c|c|c|c|c|c|c|c|c|}
\hline & \multirow{2}{*}{ Item } & \multicolumn{2}{|c|}{ TD } & \multicolumn{2}{|l|}{ D } & \multicolumn{2}{|c|}{ NS } & \multicolumn{2}{|l|}{$\mathrm{A}$} & \multicolumn{2}{|c|}{ TA } & \multirow{2}{*}{ Min } \\
\hline & & $\mathrm{n}$ & $\%$ & $\mathrm{n}$ & $\%$ & $\mathrm{n}$ & $\%$ & $\mathrm{n}$ & $\%$ & $\mathrm{n}$ & $\%$ & \\
\hline 1 & $\begin{array}{l}\text { The illustrations and explanations of the } \\
\text { teaching materials developed are clear } \\
\text { and easy to understand. }\end{array}$ & 0 & 0 & 2 & 6.67 & 1 & 3.33 & 21 & 70 & 6 & 20 & 4.03 \\
\hline 2 & $\begin{array}{l}\text { The language used is clear and easy to } \\
\text { understand. }\end{array}$ & 0 & 0 & 0 & 0 & 2 & 6.67 & 22 & 73.33 & 6 & 20 & 4.13 \\
\hline 3 & $\begin{array}{l}\text { The steps for the activities in these } \\
\text { teaching materials are easy to follow. }\end{array}$ & 0 & 0 & 0 & 0 & 1 & 3.33 & 22 & 73.33 & 7 & 23.33 & 4.20 \\
\hline 4 & The video prepared is easy to follow. & 0 & 0 & 0 & 0 & 3 & 10 & 22 & 73.33 & 5 & 16.67 & 4.07 \\
\hline 5 & $\begin{array}{l}\text { The video instruction for GSP is easy to } \\
\text { understand. }\end{array}$ & 0 & 0 & 0 & 0 & 0 & 0 & 25 & 83.33 & 5 & 16.67 & 4.17 \\
\hline 6 & $\begin{array}{l}\text { The GSP teaching materials come with } \\
\text { complete instructions and guide on how } \\
\text { to use them. }\end{array}$ & 0 & 0 & 0 & 0 & 3 & 10 & 20 & 66.67 & 7 & 23.33 & 4.13 \\
\hline 7 & $\begin{array}{l}\text { The instructions provided in the } \\
\text { teaching materials are clear and } \\
\text { sufficient. }\end{array}$ & 0 & 0 & 0 & 0 & 2 & 6.67 & 23 & 76.67 & 5 & 16.67 & 4.10 \\
\hline 8 & $\begin{array}{l}\text { The teaching materials use font types } \\
\text { and font sizes that are clear and easy to } \\
\text { read. }\end{array}$ & 0 & 0 & 0 & 0 & 5 & 16.67 & 19 & 63.33 & 6 & 20 & 4.03 \\
\hline 9 & $\begin{array}{l}\text { The colours used in the teaching } \\
\text { materials are suitable and effective. }\end{array}$ & 2 & 6.67 & 0 & 0 & 2 & 6.67 & 21 & 70 & 5 & 16.67 & 3.90 \\
\hline 10 & $\begin{array}{l}\text { The audio used is clear and appropriate } \\
\text { (it does not disturb the students' } \\
\text { attention). }\end{array}$ & 2 & 6.67 & 1 & 3.33 & 6 & 20 & 19 & 63.33 & 2 & 6.67 & 3.60 \\
\hline 11 & $\begin{array}{l}\text { The flow of information in the teaching } \\
\text { materials is easy to follow. }\end{array}$ & 1 & 3.33 & 1 & 3.33 & 1 & 3.33 & 24 & 80 & 3 & 10 & 3.90 \\
\hline 12 & $\begin{array}{l}\text { The use of images really helps in } \\
\text { understanding the teaching materials. }\end{array}$ & 0 & 0 & 0 & 0 & 1 & 3.33 & 24 & 80 & 5 & 16.67 & 4.13 \\
\hline 13 & $\begin{array}{l}\text { The size of images used in the teaching } \\
\text { materials is appropriate. }\end{array}$ & 0 & 0 & 0 & 0 & 4 & 13.33 & 22 & 73.33 & 4 & 13.33 & 4.00 \\
\hline 14 & $\begin{array}{l}\text { The answer space provided in the } \\
\text { teaching materials is appropriate. }\end{array}$ & 0 & 0 & 0 & 0 & 3 & 10 & 23 & 76.67 & 4 & 13.33 & 4.03 \\
\hline 15 & $\begin{array}{l}\text { The tables provided are appropriate for } \\
\text { the students to fill in the data obtained. }\end{array}$ & 0 & 0 & 0 & 0 & 1 & 3.33 & 25 & 83.33 & 4 & 13.33 & 4.10 \\
\hline
\end{tabular}

*SD=Strongly Disagree, $\mathrm{D}=$ Disagree, $\mathrm{NS}=$ Not Sure, $\mathrm{A}=$ Agree, $\mathrm{SA}=$ Strongly Agree

\subsection{Integration and System Testing Phase}

After all modules have been developed and tested, the researcher combined them in the integration phases to form the real system. Joomla! was used as the platform to combine all the modules. Joomla! is a type of Open Source Content Management System (CMS) that can be used for free to build a website. Figure 5 shows the interface of MyGSP system, which consists of seven main sections namely Home, Introduction, Syllabus, Teaching Materials, Download, Forum and Video Tutorial.

\subsection{Maintenance Phase}

This phase will be implemented if the system needs modification or if there is an addition of module into the system. In this phase, the comments and reports received from the users through the forum section or through the 
direct e-mails to the developer will be reviewed, assessed and evaluated. Modification will be done according to users' needs and demands if it is deemed necessary.

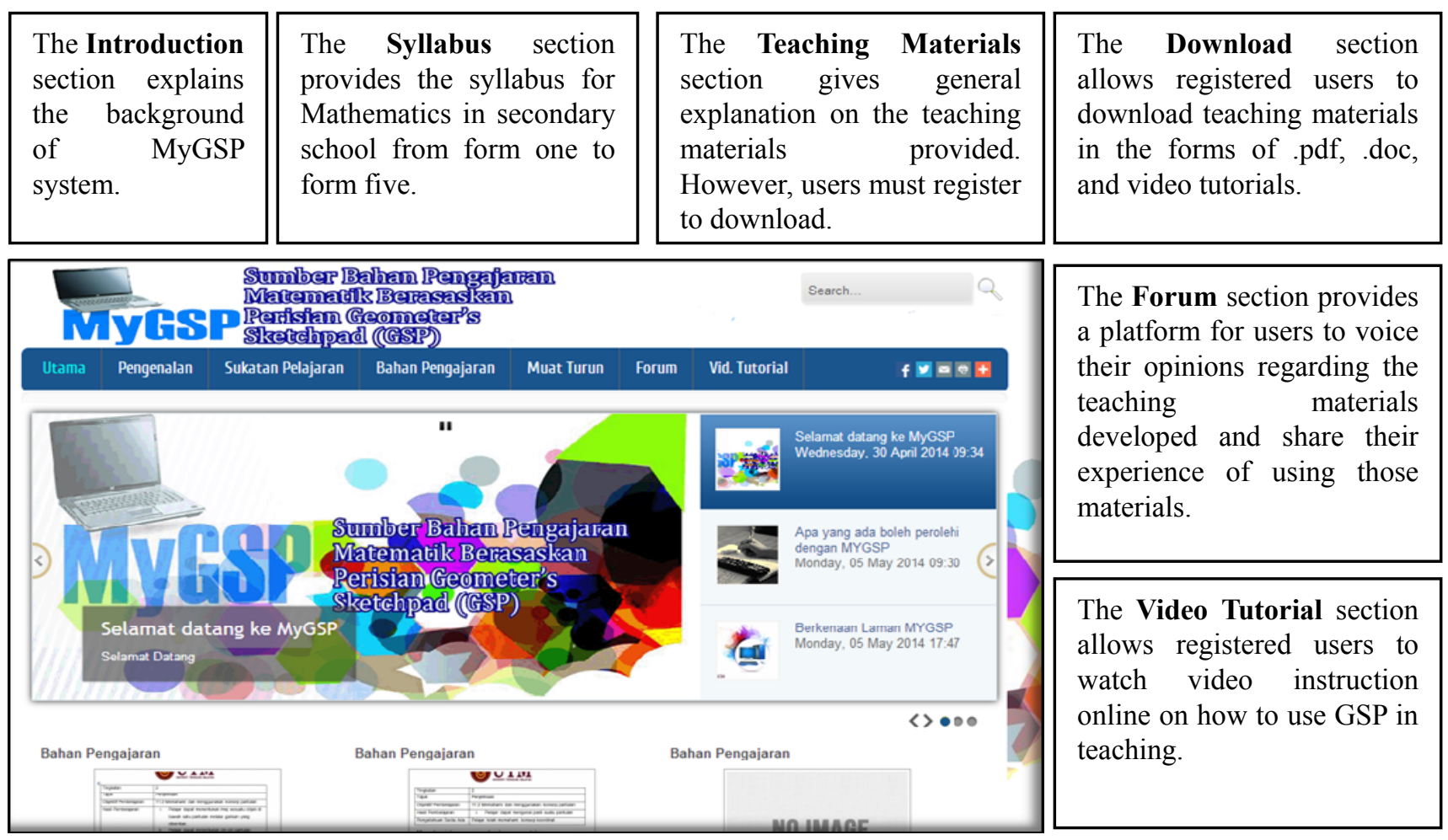

Figure 5. MyGSP system interface

\section{Discussion and Conclusion}

In this study, MyGSP system was developed as a reference for Mathematics teachers to integrate the GSP software in their teaching process in order to harness the students' HOTS. As discussed earlier, in the implementation and unit testing phase, a total of 30 pre-service teachers were asked to answer a survey regarding the materials developed in MyGSP. In the first section, which asked their perception towards the GSP software, item 1 and 5 showed the highest mean values of 4.17 and 4.13, respectively? For item 1, majority of the Mathematics teachers agreed that the GSP software was easy to learn. This finding is similar with a study by Rahim (2002) who identified the teachers' perception towards the use of GSP that was integrated in the teaching programme for teachers in Canada. In his study, most future teachers stated that the GSP software was easy to use with regard to geometry, algebra and trigonometry. Awe (2007) adds that the low cost and the ease of use have made GSP increasingly popular among educators. For item 5, most teachers agreed that GSP was very suitable as a teaching aid in KBSM Mathematics. This finding matches the study by Stols (2007) who found that pre-service teachers agreed with the idea that GSP would be very useful in the geometry class. In addition, Rahim (2002) in his study on the use of GSP by pre-service teachers in the classroom found that most of them agreed that GSP would be very useful in various branches of mathematics such as trigonometry, geometry and algebra. In the second section, which asked their perception towards teaching materials, majority of the pre-service teachers thought that the teaching materials developed were very suitable for teaching and learning. According to Nor A'idah et al. (2010), it is important for pre-service teachers to learn about GSP. Early exposure on GSP among pre-service teachers enables them to strengthen their understanding and increase their confidence to use GSP in teaching. For item 9, most of the pre-service teachers thought that students could collect data from the activities provided by the learning materials. According to Chew (2009), this is due to the fact that the GSP software with a dynamic environment manipulation has three important attributes, which are as follows: (1) students can directly manipulate the mathematical objects that are presented on the screen; (2) the mathematical objects will stay logically related when they are drawn; and (3) students will feel directly involved with the objects that they manipulate or, in other words, they are actively learning in this kind of environment. In the technical aspects, majority of pre-service mathematics teachers agreed that the teaching materials are easy to 
follow. It is hoped that MyGSP that contains Mathematics teaching materials for form one until form five based on the GSP software, and applied various teaching strategies that have been proven to harness the students' HOTS can be benefited by teachers in their teaching and learning practices.

\section{Acknowledgments}

The authors would like to thank Universiti Teknologi Malaysia and Ministry of Education for their financial support. This work was supported by the Potential Academic Staff (PAS) Grant no. Q.J130000.2731.00K58 and the Fundamental Research Grant Scheme (FRGS) Grant no. R.J130000.7831.4F426.

\section{References}

Aarnes, J., \& Knudtzon, S. (2003). Conjecture and discovery in geometry: A dialogue between exploring with dynamic geometric software and mathematical reasoning. Matematiska och Systemtekniska Institutionen.

Abdullah, A. H., \& Zakaria, E. (2012). The activities based on Van Hiele's phase-based learning: Experts' and pre-service teachers' views. Journal of Mathematics and Statistics, 8, 385-395. http://dx.doi.org/10.3844 /jmssp.2012.385.395

Abdullah, A. H., \& Zakaria, E. (2013). Enhancing students' level of geometric thinking through van Hiele's phase-based learning. Indian Journal of Science and Technology, 6(5), 4432-4446

Abdullah, A. H., \& Zakaria, E. (2013). The Effects of Van Hiele's Phase-Based Instruction Using the Geometer's Sketchpad (GSP) on Students' Levels of Geometric Thinking. Research Journal of Applied Sciences, Engineering and Technology, 5(5), 1652-1660.

Agyei, D. D., \& Voogt, J. (2010). ICT use in the teaching of mathematics: Implications for professional development of pre-service teachers in Ghana. Education and Information Technologies, 16(4), 423-439. http://dx.doi.org/10.1007/s10639-010-9141-9

Amin, N. A. M. (2008). Development and Evaluation of the Introduction to GSP District Level Course for Secondary School Mathematics Teachers. Unpublished master thesis, Universiti Putra Malaysia.

Arshad, H., Yaacob, Y., Yusof, M. M., \& Latih, R. (2000). Implications of introducing Technology in Mathematics Education. Proceedings of the International Conference on Teaching and Learning, 934-943.

Awe, W. G. (2007). How Geometer's Sketchpad Improves Student Learning. Unpublished Master Thesis. Bemidji State University.

Bahagian Pembangunan Kurikulum (BPK). (2011). Spesifikasi Kurikulum Matematik Tingkatan 3. Kementerian Pelajaran Malaysia

Becta. (2004). A review of the research literature on barriers to the uptake of ICT by teachers. Retrieved June 10, 2014, from http://partners.becta.org.uk/page_documents/research/barriers.pdf

Berns, R. G., \& Erickson, P. M. (2001). Contextual Teaching and Learning: Preparing Students for the New Economy. Retrieved November 15, 2012, from http://www.cord.org/uploadedfiles/NCCTE_Highlight05 ContextualTeachingLearning.pdf

Bingimlas, K. A. (2009). Barriers to the successful integration of ICT in teaching and learning environments: A review of the literature. Eurasia Journal of Mathematics, Science \& Technology Education, 5(3), 235-245.

Bruner, J. S. (1966). Toward a Theory of Instruction. Cambridge, MA: Harvard University Press.

Challoo, L., \& Weaver, N. (2007). Secondary Teachers' Perceptions of Utilization of Technology in the Classroom in a Select South Texas School. In R. Carlsen et al. (Eds.), Proceedings of Society for Information Technology \& Teacher Education International Conference 2007 (pp. 1429-1436). Chesapeake, VA: AACE.

Chazen, D., \& Houda, R. (1989). How to use conjecturing and microcomputers to teach geometry. Reston, VA: National Council of Teachers of Mathematics.

Choi-Koh, S. S. (1999). A student's learning of Geometry using the computer. Journal of Educational Research, 92(5), 301-311. http://dx.doi.org/10.1080/00220679909597611

Ertmer, P. A., \& Otternbreit-Leftwich, A. T. (2010). Teacher technology change: How knowledge, confidence, beliefs, and culture intersect. Journal of Research on Technology in Education, 42, 255-284. http://dx.doi. org/10.1080/15391523.2010.10782551

Gecua, Z., \& Ozdener, N. (2010). The effects of using geometry software supported by digital daily life 
photographs on geometry learning. Procedia Social and Behavioral Sciences, 2, 2824-2828. http://dx.doi. org/10.1016/j.sbspro.2010.03.422

Gillis, J. M. (2005). An investigation of student conjectures in static and dynamic geometry environments. Unpublished doctoral thesis. Auburn University.

Glass, B., Deckert, W., Edwards, B., \& Graham, K. (2001). Making better use of computer tools in geometry. Mathematics Teacher, 94, 224-230.

Gomes, C. (2005). Integration of ICT in science teaching: A study performed in Azores, Portugal. Recent Research Developments in Learning Technologies.

Guven, B. (2012). Using dynamic geometry software to improve eight grade students' understanding of transformation geometry. Australasian Journal of Educational Technology, 28(2), 364-382.

Habre, S. (2009). Geometric conjectures in a dynamic geometry software environment. Mathematics and Computer Education, 43(2), 151.

Harun, J., \& Tasir, Z. (2005). Multimedia: konsep dan praktis. Batu Caves: Venton Publishing (M).

Hirschorn, \& Thompson. (1996). Factors related to teacher use of technology in secondary geometry instruction. Journal of Computers in Mathematics and Science Teaching, 22.

Holzl, R. (2001). Using dynamic geometry software to add contrast to geometric situations-a case study. International Journal of Computers for Mathematical Learning, 6, 63-86. http://dx.doi.org/10.1023/A: 1011464425023

Idris, N. (2005). Pedagogy in Mathematics Education (2nd ed.). Kuala Lumpur: Utusan Publication Sdn. Bhd.

Johari, N. A., Chan, L. O., Ramli, R., \& Ahmat, N. (2010). The Effect of GSP on Students' Understanding in the Graphs of Trigonometric Functions. Paper presented at Fifteenth Asian Technology Conference in Mathematics (ATCM) on 17-21 December 2010 at University of Malaya Kuala Lumpur.

Kedah, J. P. N. (2009). Laporan Latihan dan Penggunaan Geometer's Sketchpad (GSP) Dalam Pengajaran dan Pembelajaran Matematik Di Sekolah Menengah. Borang GSP/P\&P/SM 1/2009.

Kerrigan, J. (2002). Powerful software to enhance the elementary school mathematics program. Teaching Children Mathematics, 8(6), 364-377.

Lange, G. V. (2002). An experience with interactive geometry software and conjecture writing. The Mathematics Teacher, 336-337.

Manizade, A. G., \& Lundquist, B. (2009). Learning about proof by Building Conjectures. PMENA 2009 Conference Proceedings. Atlanta, Georgia, September 2009.

Meng, C. C. (2009). Assessing pre-service secondary mathematics teachers' geometric thinking. Proceedings of the 5th Asian Mathematical Conference. Malaysia 2009.

Mumtaz, S. (2000). Factors affecting teachers' use of information and communications technology: A review of the literature. Journal of Information Technology for Teacher Education, 9(3), 319-341. http://dx.doi.org/ $10.1080 / 14759390000200096$

NCTM. (2002). Principals and Standards for School Mathematics. National Council of Teachers of Mathematics, Reston: VA.

Newman, C. (2000). Online testing rated. Advertising-Age, 71(20), 64.

Nordin, N., Zakaria, E., Mohamed, N. R. N., \& Embi, M. A. (2010). Pedagogical Usability of the Geometer's Sketchpad (GSP) Digital Module in the Mathematics Teaching. The Turkish Online Journal of Educational Technology, 9(4), 113-117.

Olkun, S., Sinoplu, N. B., \& Deryakulu, D. (2005). Geometric explorations with dynamic geometry applications based on Van Hiele levels. International Journal for Mathematics Teaching and Learning (April 13). Retrieved from http://www.cimt.plymouth.ac.uk/journal/default.htm

Osman, K. C. (2006). Meninjau penggunaan Geometer Sketchpad (GSP) di kalangan guru matematik sekolah menengah Pulau Pinang. Unpublished M.Ed thesis, Universiti Sains Malaysia, Penang.

Ozden, M. (2007). Problems with science and technology education in Turkey. Eurasia Journal of Mathematics, Science \& Technology Education, 3(2), 157-161.

Pa, N. A. N. (2008). Isu-isu kritikal dalam pendidikan matematik. Kuala Lumpur: Penerbit Universiti Malaya. 
PPK. (2000). Huraian sukatan pelajaran matematik KBSM. Kementerian Pendidikan Malaysia.

Rahim, M. H. (2002). A classroom use of the Geometer's Sketchpad in a mathematics pre-service teacher education program. Retrieved February 22, 2002, from http://math.unipa.it/ grim/Jrahaim

Rooney, C. (2012). How am I using inquiry-based learning to improve my practice and to encourage higher order thinking among my students of mathematics? Educational Journal of Living Theories, 5(2), 99-127.

Saidin, K., \& Sam, L. C. (2013). Mathematics Teachers' Levels of Use of Geometer's Sketchpad: Where is the Pinnacle? Proceedings of the 20th National Symposium on Mathematical Sciences, 285-291.

Salehi, H., \& Salehi, Z. (2012). Integration of ICT in language teaching: Challenges and barriers, 215-219. In Proceedings of the 3rd International Conference on e-Education, e-Business, e-Management and e-Learning (IC4E, 2012), IPEDR.

Shiang-tung, \& Feng-chu. (2008). Conjecture activities for comprehending statistics terms through speculations on the functions of imaginary spectrometers. Australian Mathematics Teacher, 64(3), 17-24.

Stols, G. H. (2007). Designing mathematical-technological activities for teachers using the Technology Acceptance Model. Pythagoras, 6, 10-17.

Topracki, E. (2006). Obstacles at integration of schools into information and communication technologies by taking into consideration the opinions of the teachers and principals of primary and secondary schools in Turkey. Journal of Instructional Science and Technology (e_JIST), 9(1), 1-16.

Van De Walle, J. A. (2004). Elementary and middle school mathematics (5th ed.). Boston: Allyn and Bacon.

Vrasidas et al. (2010). Teacher Use of ICT: Challenges and Opportunities. Paper presented at the Networked Learning Conference in Denmark.

Wilkinson, J. W. (1999). The contextual approach to teaching Physics. Australian Science Teachers Journal, $45(4), 43-50$.

\section{Copyrights}

Copyright for this article is retained by the author(s), with first publication rights granted to the journal.

This is an open-access article distributed under the terms and conditions of the Creative Commons Attribution license (http://creativecommons.org/licenses/by/3.0/). 